\title{
Communicative Competence Diagnostics of Future Secondary Educational Institutions Managers as Leading Educators
}

\author{
Tamara Turchyn \\ Department of Pedagogics, Primary Education and Education Management \\ Nizhyn Mykola Gogol State University \\ Krugova Street 56/1, 14005 Chernihiv \\ Ukraine \\ e-mail: tamarat2013@ukr.net \\ Stepan Vozniak \\ Research Department \\ Kyiv National Defence University of Ivan Chernyakhovsky \\ Tupoleva Street 7, 03049 Kyiv \\ Ukraine \\ e-mail: step_voz@ukr.net \\ Oksana Soshko \\ Department of Foreign Philology and Translation \\ Kyiv National University of Trade and Economics \\ Kioto 19, 19410 Kyiv \\ Ukraine \\ e-mail: ok_soshko@ukr.net
}

\begin{abstract}
Our paper is devoted to the research of professional communicative competence of future managements of secondary educational institutions. It reveals the meaning and the structure of the concept of "communicative competence of managers in the field of education". The research is described, and the results of experimental work are analysed in order to develop professional communicative competences of the future secondary educational institutions managers.

At the ascertainment/initial stage of the experiment the authors defined the criteria and levels of professional communicative competence for the future managers of the secondary education institutions, and the choice of methods of diagnostics was grounded. The obtained results of scientific research can be used in training of managers in the sphere of education and for qualification improvement of secondary educational institutions managers.
\end{abstract}

\section{Introduction}

In the educational system at the present stage, changes connected with the requirements of innovativeness of its character, content value orientation, as well as changes in the direction and mobility of the organizational structure, is taking place. These changes include both positive and negative sides, which require solutions. Formation of the educational system is focused on the effective management and efficient implementation in practice of educational institutions of modern scientific and educational achievements in the field of management.

A personality-oriented management strategy requires the leaders of educational institutions to be innovative, their conceptual and strategic thinking, the ability to design a humanitarian and communicative space for implementing managerial actions, taking into account socio-cultural factors and the willingness of management subjects to communicate effectively. Communication itself, along with decision-making procedures, is a common characteristic of invariant control functions, creating a favourable environment for the effective implementation of the latter.

An important component of the professional competence of the educational institution leader is his communicative competence, which is personally socially significant and allows to implement the leading principles of education system modernization. Social expectations suggest the emergence of a new type of educational manager, who is ready to solve communication problems, create comfortable conditions for communication of all participants in the educational process. At the same time, it should be noted that educational managers, who are able to work in modern conditions are not enough. In this regard, in pedagogical theory and practice, an urgent problem is presented - the organization of productive communication in the field 
of education. Solving this problem involves improving the communicative competence of managers. Therefore, the program development for the formation of communicative competence of future educational institutions managers as educational leaders is a priority.

Many scientists investigated the problem of educational managers' communicative competence. Yefimochkina (2018), Obushak (2006), Rozhdestvenskaya (2000), Chechel (Chechel et al. 2014) studied the professional pedagogical culture and communicative competence of educational institutions; Androsova (2015) was engaged in the development of the directors' professional competence, Lazarenko (2000) studied formation of school managers' image, Kutsenko (2001) investigated the school manager's language mastery, Parpura (2008) studied the value attitudes of school managers to self-improvement in their communicative competence; Osipova (2017) - the relationship between communicative competence and flexibility with communicative creativity.

A study conducted by Peresypkin (2002) shows that the school director still treats teachers as objects of management rather than as active participants, therefore, the monological type of communication still dominates when discussing issues and problems of an educational institution, etc.

\section{Communicative competence of the education manager as an integrative formation}

One of the main competencies of the educational manager is communicative competence, which ensures effective socialization, optimal interpersonal mutual atmosphere in the institution. Communicative competence is aimed at obtaining important information, demonstrating and defending one's own position in a dialogue and statements based on respect for the values of others (Menkin 2011).

Communicative competence is associated with willingness to professional reflection, self-realization and self-improvement (Parpura 2008).

Scientists interpret the phenomenon of "communicative competence" in different ways: 1) as a set of skills and abilities necessary for successful communication (Petrovskaya 2007); 2) as situational adaptability and fluency in verbal and non-verbal means of social behaviour, as a criterion of communicative competence, as a level of success of planned influence acts and used means of reproduction of impression on others (Yemelianov 1983); 3) as a concept of internal resources needed to build effective communication in the current circle of situations of interpersonal interaction (Stolyarenko 2015); 4) as the ability, skill, knowledge, sufficient and adequate, to be achieved (Sydorenko 2007). According to the above-mentioned approaches of researchers, the essence of communicative competence can be represented as the ability and willingness to enter into various kinds of contacts (non-verbal and verbal, oral and written) for solving communicative problems (transferring information, negotiating, establishing and maintaining contacts).

Communicative competence, in our opinion, is a person's willingness and ability to build optimal interpersonal interaction, taking into account generally accepted norms of the communicative community, language etiquette and communicative situation. Communicative competence of an educational manager is his feature to ensure effective interaction with various participants in the educational process, organizations, government authorities; ability to prevent and resolve difficult situations and conflicts; to encourage a partner to clarify his position; also the skills of public speaking and active listening (ability to hear and understand a partner), ability to reason and persuade, as well as the ability to motivate subordinates.

Thus, it appears that communicative competence of the manager of a general educational institution is an integrative formation, which consists of communicative abilities, the exchange of knowledge, skills, abilities which meet the communicative tasks and are sufficient to solve them.

Lomov (1984) considers communicative competence as a process of providing multifunctional communication, identifies by its content such parties or functions as: "information and communication", covering the processes of receiving and transmitting information; "regulatory-communicative" related to mutual adjustment of actions in the implementation of joint activities; "effective and communicative" refers to the emotional sphere of a person and meets the needs of changing his emotional state".

Components that influence the formation of communicative competence of the educational manager: lexical richness, well-developed speech; ability to carry out socio-psychological forecast of communicative situation, in which communication should occur, and then to program the process of communication taking into account the communicative situation; ability to adhere to communication etiquette, ethics, ability for productive interpersonal interaction; ability to implement socio-psychological management of communicative processes in educational institution; knowledge of communicative tactics and strategies and of personal characteristics, typical problems to be solved; ability to decode nonverbal communication of a partner; stress resistance as the ability to psychophysical self-regulation; assertiveness, self-confidence; public speaking ability and ability to listen to the interlocutor actively; ability to organize business meetings, presentations as well as negotiation skills; empathy as the ability to sympathize and understand human needs. 
Communicative competence in managerial communication requires the manager to know basic rules and regulations of interpersonal interaction, adaptability and ability to use freely all means of communication, flexibility and adequacy in the choice of psychological positions, relevant personal qualities.

\section{Structure of communicative competence of the manager of educational institution}

Structure of communicative competence of the manager of educational institution, in our opinion, has the following components:

- Personal communication skills (characterizing the attitude to the method of communication, development of need for communication);

- Communicative abilities (determine the activity and initiative in communication, emotional response to the partner's state, the possibility of implementing an individual communication program);

- Communicative ability (knowledge of norms and rules of communication, proficiency in psychotechnics and communication technology in general).

Thus, a theoretical analysis of the problem allows to state that the communicative competence of the general educational manager is a complex holistic system that is to be structured. So, let's look at the components of managers' communicative competence. Taking into account the accepted psychological pedagogical terminology, it seems possible to determine the structure of a specific definition by distinguishing the following components, respectively: cognitive; reflexive; activity-communicative; motivational.

The study was conducted in order to develop professional communicative competence of the future manager of the complex educational training; it was carried out in 2 stages. At the first stage, criteria for assessing the level of communicative competence for future general educational managers and methods for their detection were determined; at the second stage, the level of professional communicative competence of future managers (obtaining a master's degree) was compared with the level of the general educational managers.

The components, criteria and indicators of communicative competence formation of future educational managers as leading educators are presented in Table 1 below.

Formation of the cognitive, reflective, activity-communicative and motivational components of future managers was revealed using certain research methods, which were characterized by the degree of representativeness, reliability, validity.

Based on the content of communicative competence for future managers in the field of education, we defined the criteria for the development of cognitive, reflective, activity-communicative and motivational components of integrative communicative competence, we identified three levels of its development: intuitivesituational; functionally adequate; initiative-creative.

All three levels are closely related to each other, and each previous one includes the following:

- intuitive-situational level - the knowledge of future leaders in the field of professional communication is superficial, inactive; masters do not know how to conduct dialogue; are not able to predict the content and analysis of a specific managerial communication situation; poor knowledge of effective listening that impedes productive communication; future managers have difficulty in contacting people; indifferent to the experiences of another person; inadequate assessment of their own actions in communication management situations, lack of need for self-actualization and self-improvement in the field of communication;

- functionally adequate level of knowledge in the field of communicative management is empirically situational, with partial generalization; future managers are able to conduct dialogue, but at low level; have a situational ability to predict the content and analyse the specific management situation of communication and to choose from the speech techniques and means of communication; possess poor listening skills, which impedes productive interaction; able to find optimal ways of communication, leading to the development of goodwill; level of development, dynamics of personal growth, but not in all situations of communication; awareness of the requirements of society related to the formation of future managers of professional communicative competence; there is a capacity for self-realization and self-improvement in communication sphere, but not in all situations;

- initiative-creative level of knowledge in the field of professional communication has a deep theoretical character, systemic and holistic; future managers are able to competently conduct a dialogue; able to predict the content and analyse the specific situation of communication and to get speech means and communication techniques; possess effective listening skills which promote productive communication; easily establish contacts with other people; ability to consciously control the results of their activities, level of development, dynamics of personal growth; constant need for self-realization and development in the sphere of communication. 
Table 1. Components, criteria and indicators of the formation of communicative competence for future managers and directors of general educational institutions as leaders in the sphere of education

\begin{tabular}{|c|c|c|}
\hline $\begin{array}{l}\text { Components of } \\
\text { communicative } \\
\text { competence of } \\
\text { future managers }\end{array}$ & $\begin{array}{l}\text { Criteria for forming the communicative competence of future } \\
\text { managers }\end{array}$ & Diagnostic tools \\
\hline Cognitive & $\begin{array}{l}\text { Semantic: knowledge of communication tactics and strategies; } \\
\text { peculiarities of communication management in the educational } \\
\text { process of the institution, the basic laws of cooperative } \\
\text { communication and the rules of interpersonal interaction, } \\
\text { etiquette; knowledge of verbal, non-verbal, and paraverbal } \\
\text { communications and influences, their functional synonyms and } \\
\text { congruence; awareness of systematic classification of linguistic } \\
\text { means, which are used in different common situations of } \\
\text { communication; adequate orientation of the specialists in } \\
\text { themselves, interlocutors, in the situation of professional } \\
\text { communication and specific communicative and professional } \\
\text { purposes, knowledge of communicative culture }\end{array}$ & $\begin{array}{lr}\text { Author's Test } & \text { "Level of } \\
\text { awareness } & \text { in } \\
\text { communication } & \text { and } \\
\text { linguistics". } & \end{array}$ \\
\hline \multirow[t]{2}{*}{ Reflexive } & $\begin{array}{l}\text { Affective value: understanding preconditions, patterns and } \\
\text { mechanisms of the professional activity by future managers; } \\
\text { objective reflection and evaluation of one's own actions in the } \\
\text { process of focused professional self-development; reflexive skills } \\
\text { in the ability to perform communication and management } \\
\text { activities }\end{array}$ & $\begin{array}{l}\text { Sinyavsky and Fedoryshyn } \\
\text { communication skills self- } \\
\text { assessment test (Burlachuk } \\
\text { 1999); }\end{array}$ \\
\hline & $\begin{array}{l}\text { Ability to consciously control the results of one's communicative } \\
\text { activities, the level of one's own communicative development, } \\
\text { dynamics of personal growth: formation of such important } \\
\text { qualities as initiative, communicative openness, willingness to } \\
\text { cooperate, tendency to introspection, anticipate the situation of } \\
\text { communication }\end{array}$ & $\begin{array}{l}\text { "Emotional Intelligence" } \\
\text { Hall diagnostics } \\
\text { (Sydorenko 2007); }\end{array}$ \\
\hline \multirow[t]{5}{*}{$\begin{array}{l}\text { Activity- } \\
\text { communicative }\end{array}$} & $\begin{array}{l}\text { Operative behavioural: } \\
\text { Ability to predict the content of communicative situation; }\end{array}$ & $\begin{array}{l}\text { Maximov and Lobeyko’s } \\
\text { test «Determining the style } \\
\text { of interpersonal } \\
\text { interaction» (Burlachuk } \\
\text { 1999); }\end{array}$ \\
\hline & $\begin{array}{l}\text { Ability to analyze a specific managerial situation of } \\
\text { communication and choose from communicative speech } \\
\text { techniques. }\end{array}$ & $\begin{array}{l}\text { Test of adaptation by Y. } \\
\text { Gilbukh "Communication } \\
\text { Skills" (Petrovskaya 2007) }\end{array}$ \\
\hline & $\begin{array}{l}\text { Ability to listen to and choose verbal and non-verbal behaviour } \\
\text { according to the communicative situation; }\end{array}$ & $\begin{array}{l}\text { Listening Skills Test } \\
\text { (Kozyrev 2008) }\end{array}$ \\
\hline & & $\begin{array}{l}\text { Author's method «Stories } \\
\text { about yourself» }\end{array}$ \\
\hline & Ability to motivate teamwork of the head and subordinates & $\begin{array}{l}\text { Test "Head through the } \\
\text { Eyes of Subordinates" } \\
\text { (Podolyak 1989). }\end{array}$ \\
\hline Motivational & $\begin{array}{l}\text { Subjective-oriented: } \\
\text { positive motivation for self-improvement in the sphere of } \\
\text { communication }\end{array}$ & $\begin{array}{l}\text { Questionnaire «My attitude } \\
\text { to communicative activity } \\
\text { in the sphere of } \\
\text { management» }\end{array}$ \\
\hline
\end{tabular}

Source: Own results

\section{Methodology and results}

In order to verify the conceptual ideas on which the study is based, we have conducted an experiment which was organized on the basis of Mykola Gogol Nizhyn University. The sample consisted of 75 graduate students of specialty 073 "Management" and 75 heads of schools in Kyiv, who have diplomas in the mentioned specialty. The level of the communicative competence of future managers for a cognitive component was determined by diagnosing the isolated indicators of content criterion.

To clarify the awareness of future managers regarding the essence of effective communication; knowledge of communication specifics in the sphere of linguistic activity; knowledge of cooperative communication laws, we developed the questionnaire "Level of awareness in communication and linguistics". It consisted of 2 parts: knowledge of cooperative communication laws; linguistic knowledge. Each part included 10 
questions. Next to the question was indicated the number of points received by a respondent for the answer. The level of knowledge is determined in total: intuitive-situational level of knowledge-from 1 to 30 points, the functionally-adequate-from 31 to 60 , initiative-creative-from 61 and onwards.

Due to the limited scope of the article, we give answers to individual questions of the questionnaire. To the question "What is professional and pedagogical communication?" only $9 \%$ of future managers and $11 \%$ of school heads were able to give a complete and reasoned response. To the question "How do you know the laws of communication?" $13 \%$ of future managers and $12 \%$ of managers were able to name 12 laws, and the rest from 3 to 5 laws. On the question "What main styles of corporate communication do you know?" only 8\% of masters and $7 \%$ of managers gave the full answer: "Ritual, humanistic, manipulative".

To the question "What communicative tactics and strategies do you know?" only $10 \%$ of future managers and $8 \%$ of managers named all 8 strategies: proposals strategies, local coherence strategies (connections), macro strategies, schematic, production, stylistic, rhetorical, non-verbal, conversational strategies.

To the question "What types of interpersonal interactions do you know?" 9\% of masters and 10\% of managers answered "assimilation, adaptations, competitions and conflict in the park", the rest named separate ones - "cooperation, conflict".

Only $10 \%$ of masters and $11 \%$ of managers were almost complete in answering the question "What are the rules of productive interpersonal interaction?" Among the rules were the following: "1) before communication, it is necessary to clearly define the ideas that are put into the message; 2) analyze the true purpose of each communicative situation; 3) when planning a communicative situation consult with colleagues, consider the opinions of communication partners; 4) pay close attention to intonation and main message content; 5) try to include in the message something useful and valuable to its addressee; 6) keep the communicative process in sight; 7) think and predict communicative situations for the future; 8) learn to listen carefully".

Responses of future managers and directors to the question "What styles of speech and language are characterized by them for use in various communication situations" were: $12 \%$ of future managers and $13 \%$ of directors indicated 6 styles of speech and fully characterized them, 73\% of masters and 70\% of managers named 6 styles of speech and characterized their individual means; $15 \%$ of masters and $17 \%$ of managers named 5 styles of speech and described their individual means.

When asked by the questionnaire "Describe types of listening, identify the disadvantages and benefits of each type", $8 \%$ of graduate students and 9\% of managers answered that there are 2 types of listening, characterized all situations where reflexive and non-reflexive listening is useful; the rest $-92 \%$ of graduate students and $92 \%$ of managers named 2 types of listening and were able to identify only certain situations in which reflexive and non-reflexive listening is useful.

When asked by the questionnaire "What are the 5 basic rules of effective listening", we received the following answers: $9 \%$ of graduate students and 10\% of managers thought that "this is respect for the interlocutor; sincerity in making contact; establishing eye contact; carefully analyze the communication situation and not draw conclusions in advance"; $21 \%$ of graduate students and $20 \%$ of managers believe that "it is not necessary to give freedom to emotions, to listen carefully to a partner in communication"; $70 \%$ of future managers and directors - "respect your communication partner; do not dominate; keep up the conversation".

An analysis of the responses of future leaders and managers in the field of education showed that more than $80 \%$ of respondents have a superficial understanding of the essence of effective communication; specifics of communication in the field of language activity; laws of cooperative communication; linguistic concepts.

As it was found out, awareness of the essence of effective communication; specifics of communication in the field of language activity; laws of cooperative communication; the linguistic concepts of the cognitive component at the ascertaining stage of the experiment were mostly at the functionally adequate and intuitivesituational level, with quantitative indicators of distribution by levels of future managers and school directors were approximately the same: $13.5 \%$ of graduate students and $14 \%$ students surveyed level; $48 \%$ of graduate students and $47 \%$ of managers have a functionally adequate level, $38.5 \%$ of graduate students and $39 \%$ of directors have an intuitive situational level.

Therefore, the need for further development of the identified component of the communicative competence development of future educational managers is indisputable in the specially organized educational process of higher education. The level of development of communicative competence of future managers by the reflexive component was determined by the diagnosis of isolated indicators of affective-value criterion.

In order to determine the self-esteem of future leaders of reflexive skills in the ability to perform communication and management activities, we used the test of Sinyavsky and Fedoryshyn for self-assessment of communicative abilities (Burlachuk 1999). According to the results of the test, it was found that the quantitative indicators of the distribution of self-esteem of reflective skills in the ability to perform communicativemanagement activities at the levels of future managers and executives were approximately the same: in $9 \%$ of surveyed graduate students and $10 \%$ of managers stated the initiative-creative level; $43 \%$ of graduate students and $45 \%$ of managers have a functionally adequate level, $48 \%$ of graduate students respondents and $45 \%$ of managers have an intuitive situational level. 
In order to identify in future managers (in comparison with school leaders), the ability to consciously monitor the results of their communicative activities, to diagnose their level of communicative development, personal growth dynamics: such important qualities as initiative, communicative openness, willingness to cooperate, co-creation, tolerance, tendency to introspection, ability to improvise, creative imagination, foresight, we used the diagnostics of Hall's "emotional intelligence" (Sydorenko 2007).

According to the test results, the quantitative indicators of distribution on the level of future managers and directors "emotional intelligence" differ insignificantly: $20 \%$ of graduate students and $21 \%$ of managers have their own proactive and creative level. $51 \%$ of graduate students and $53 \%$ of managers have a functionally adequate level, $29 \%$ of graduate students and $26 \%$ of managers have an intuitively situational level.

As the study showed, indicators of the development of communicative competence of future managers and teachers by the reflective component of the affective-value criterion at the ascertainment stage of the experiment were mostly at the functionally adequate and intuitive-situational levels, and the quantitative indicators of distribution were equal to the levels in $14.5 \%$ of the surveyed graduate students and $15.5 \%$ of managers, the initiative-creative level was stated; in $47 \%$ of graduate students and $49 \%$ of managers functionally adequate level, in $38.5 \%$ of graduate students and $35.5 \%$ of managers - intuitive-situational level.

The level of development of communicative competence of future managers on the active-communicative component was determined by the diagnostics of the singled-out indicators of operative-behavioural criterion.

In order to identify in future managers (in comparison with the school directors) the ability to predict the content of the communication situation, we used the methodology by Maximov and Lobeyko "Determining the style of interpersonal interaction" (Burlachuk 1999). The methodology made it possible to establish the dominant personality management style of the future leader in accordance with Management styles: directive, collegial, non-interference in actions of others, business.

The test results show that the quantitative indicators of the distribution of the ability to predict the content of communication situation of future managers and directors are different: $18 \%$ of surveyed graduate students and $10 \%$ of managers found initiative-creative level, since the total indicator (by questionnaire) of respondents in this group was $70-80$ points, which showed the orientation to interaction with people, the ability to predict the content of the communication situation; $42 \%$ of graduate students and $38 \%$ of managers have a functionally adequate level, since the respondents of this group showed a tendency to directive and non-interference style; $40 \%$ of graduate students respondents and $52 \%$ of managers have an intuitive situational level that characterized the group as passive individuals in group activities. As we can see, a significant number of directors, in comparison with future managers, are prone to directive style of interpersonal interaction, which indicates the presence of professional deformation in the activities of managers.

To determine the level of ability to analyse a specific communication management situation and to select speech and communication techniques, we used the Hilbuch test "Communication skills" (Petrovskaya 2007). According to the test questions, the ways of communication of respondents in communication situations (dependent, competent, aggressive) were determined.

According to the results of the test, it is established that quantitative indicators of distribution ability to analyse specific management situation of communication with future managers and directors differ: $13.5 \%$ of masters and $11 \%$ managers were attributed to the proactive and creative level, as the respondents of this group discovered the competent way to communicate in communication situations, found the ability to give and accept signs of attention from colleagues and interlocutors; adequate reactions to a fair and unjust criticism, provocations by the interlocutor; $46 \%$ of students and $37 \%$ of managers are at functionally adequate level, since the respondents of this group found a tendency to aggressive communication; $40.5 \%$ of graduate students respondents and $52 \%$ of managers are at the intuitively-situational level that characterised representatives of this group as passive personalities in group activities. As we can see, a significant number of directors compared to future managers are inclined to aggressive way of communication, which indicates the presence of professional deformation in management activities.

In order to determine the level of ability to listen and choose verbal and non-verbal behaviour according to the communicative situation, we used the "Listening Skills" Test (Kozyrev 2008). The methodology made it possible to evaluate the skills of effective listening, during which the content, context and mood of the interlocutor were perceived, which allowed to choose the verbal and non-verbal behaviour of the respondents.

The results of the test showed that the quantitative indicators of the distribution of the ability to listen and choose verbal and non-verbal behaviour according to the communicative situation of future managers and directors differ insignificantly: $14 \%$ of the surveyed graduate students and $12 \%$ of managers were attributed to the initiative-creative level; $46 \%$ of graduate students and $42 \%$ of managers - at functionally adequate level, $40 \%$ of graduate students and $46 \%$ of managers - at intuitive-situational level.

In order to determine the level of ability to reasonably motivate the joint work of the manager and subordinates Podolyak's test (1989) "Head through the eyes of subordinates" was used. Using the questionnaire, we evaluated three parameters of the director: competence of the leader, his professional skills; emotionality of 
the director, his ability to demonstrate responsiveness and kindness, attention and humanity; demanding and justice of the leader, his ability to interact with subordinates.

According to the test results, it was found that quantitative indicators of the level of distribution of skills to motivate the joint work of the head and subordinates are slightly different for future managers and directors: 0 , $5 \%$ of surveyed graduate students and $9 \%$ of managers are at proactive and creative level; $41 \%$ of graduate students and $50 \%$ of managers - at functionally adequate level, $48.5 \%$ of graduate students and $41 \%$ of managers are at an intuitively-situational level. A smaller number of managers with an intuitively situational level of skills to motivate the joint work of the leader and subordinates compared with graduate students explain the ability of managers to realize their managerial potential in the educational process.

We have tested the level of speech skills of future managers using the author's methodology "stories about ourselves". Due to the limited volume of the article, we only provide answers to some of the survey questions.

We began to analyse the stories by examining their narrative deployment and linguistic complexity. We made conclusions on the relative linguistic complexity of the statements of future managers and directors by the average number of complex and simple sentences in them, as well as by the presence of different types of sentences in the texts. We received the most detailed texts in the group of directors - the average length of the text is 7.5 sentences. Graduate student texts were slightly shorter -6.6 sentences. At the same time, the ratio of the number of complex and simple sentences in the texts in both groups is in favour of the simple ones, although the directors have almost equal average number of simple and complex sentences per text (3.74 and 3.64).

Directors, compared to the graduate students, wrote more detailed texts of medium length, with almost equal numbers of simple and complex sentences. As for the variety of types of sentences used in the statements of future leaders and managers in the field of education, we noticed the dominance of imperative sentences $(6.92$ out of 7.5 for directors and 6.22 out of 6.64 for graduate students). We associate this with the greater general emotionality of leaders, their great aspiration to share their feelings, worries about any life events and their attitude towards them, as well as the specifics managerial style of activity of many of them, aspiration to use the imperative design of the order, requirements, prohibitions, appeals, and warnings. Therefore, we received more emotional texts from them than from graduate students, but still not as many as expected. Perhaps, when the subjects talked about themselves orally, the necessary emotionality was achieved through intonation, pitch, facial expressions and gestures. And when they need to express their emotions and feelings in writing, subjects have experienced a lack of necessary language and techniques. Thus, we can talk about greater emotionality of directors compared to magistrates, as well as lack of the ability to express their emotions, feelings and experiences with linguistic and figurative means in written statements in the respondents of both groups. The latter assumption is supported by a small number of epithets in the texts of the respondents. So, graduate students used 2.4 single-word and 0.59 two or more-word epithets in sentences of 78 words, the heads used 2.3 singleword and 0.43 two-and-more word epithets in sentences of 78 words. Naturally, the number of epithets in different texts was different. Most of the epithets used by the respondents were simple, but not complex: "cry of joy", "first aid", "iron character", "creative silence", "cheerful temper", "majestic look", "trembling soul", "bright voice", "prophetic word", etc. In this regard, the emotionality, brightness and expressiveness of statements about extremely interesting and unusual events significantly decreased.

In addition, statements rarely met metaphors and comparisons: $0.06,0.07$ metaphors in the text, and 0.04 and 0.1 comparisons according to directors and graduate students. And if a small number of metaphors in their stories can be explained by a small "artistry" of everyday "conversational" texts, then, in our opinion, a small use of comparisons is rather strange, because comparison is simpler than a metaphor, an artistic tool. That allows you to give brightness, clarity and imagery of the narrative. In few other cases, these were either borrowings from poems by other authors, or rather well-established and often used metaphorical constructions, for example, "hard road of life", "life to live - not a field to cross", "life mist", "wisdom covers your head" , "I am a lonely star," "put a piece of one's soul in me", "sensitive issues", etc.

As for the comparisons, the statements of directors and masters used mostly established language constructions: "I am like a fire in the woods", "I am a fire element", "life is like a vicious circle", "I am like a cat" "my life is like a whirlwind of difficult events".

We also evaluated the complexity and expressiveness of the interviewees by the number of figurative expressions, "original" words and expressions, "catch phrases" and literary and linguistic stamps. Directors and future managers were found to have a low relative image frequency $(0.15$ expressions per text for graduate students, 0.18 expressions for directors) and an even lower frequency of using "catch phrases" (0.02 phrases per text for graduate students, 0.08 - at directors). The overwhelming number of statements of the respondents of both groups was characterized by generality, simplicity of linguistic constructions and a small number of linguistic means.

In addition, in the respondents' statements we noticed a significant number of so-called literary and linguistic stamps (2.04 per text for masters and 2.68 for directors). For example, "I am not afraid to be funny or weak", "time is not standing still", "I have fulfilled my dream", "got a decent job", "with tears in my eyes" and others. Most often, language stamps were used by graduate students compared to directors. We attribute this to 
the fact that graduate students seem to have less experience in role communication, which requires knowledge of a certain "language rule" about formal communication than managers.

Thus, we can state that the respondents of both groups have a limited repertoire of linguistic techniques and means, characterized by a small percentage of expressive sentences, and the prevalence of simple sentences over complex, average vocabulary is within the generally accepted, "everyday" and business style, simple and common epithets (with the predominance of monosyllabic epithets over phrase-epithets), an extremely small number of metaphors, comparisons and other expressive literary devices, practically due to the lack of "original words", a small number of figurative expressions and "winged phrases" and a significant percentage of literary, linguistic clichés in texts. Leaders have a more relevant use of language techniques and tools in their statements than masters, theirs are less significant.

According to the test results, it turned out that the quantitative indicators of the distribution of speech skills of future managers and directors did not differ significantly: $18 \%$ of the surveyed masters and $19.5 \%$ of managers were attributed to the initiative and creative level; $49 \%$ of graduate students and $53 \%$ of managers have a functionally adequate level, $33 \%$ of graduate students respondents and $27.5 \%$ of managers have an intuitive level.

The indicators of the development of competence of future managers in the activity-communication component at the final stage of the experiment were mostly at the functionally adequate and intuitive-situational level, while quantitative indicators of distribution by levels of graduate students and managers were about the same: $14.3 \%$ of the surveyed masters and $12.8 \%$ of directors were found at the initiative-creative level; $44.8 \%$ of graduate students and $44 \%$ of managers - at the functionally adequate level, $40.4 \%$ of graduate students respondents and $43.7 \%$ of managers were at the intuitive situational level.

Therefore, the need for further development of the identified component of the development of communicative competence of future education managers is indisputable in the specially organized educational process of higher education.

The level of development of communicative competence of future managers by the motivational component was determined by diagnosing the subject-orientated criteria.

In order to determine the positive-active attitude to communication activity, positive motivation for selfimprovement in the field of graduate students' communication, we developed and tested the questionnaire "My attitude towards communication-management activity". Future managers and directors had to give full answers to 10 questions.

Let us analyse the answers to some questions. We received the following answers to the question "Do you feel the need to gain knowledge in the field of communication psychology and communication management?": $52 \%$ of graduate students and $48 \%$ of directors feel such a need, "since the study of these subjects is important not only for the manager, but also for any person"; "Communication psychology and communication management reveal some important aspects of communication ethics in managerial behaviour" (18\% of graduate students and $19 \%$ of managers); "Communicative management helps to master the skills of public speaking, which cannot be avoided in the professional activity of the manager" (26\% of future managers and $27 \%$ of directors); "Knowledge of the psychology of communication helps to better understand the reasons for the actions of communication partners, knowledge of communicative management is always relevant, as the manager's personality must be constantly improved" (4\% of graduate students and 3\% of managers).

The answers to the question "What motivated you to study communication psychology and communication management?" were: the desire to get good grades and credit on the subject $(28 \%$ of future managers and $32 \%$ of directors); career development (41\% of graduate students and $33 \%$ of managers); the desire to improve their level of knowledge and to develop certain skills (31\% of graduate students and $30 \%$ of directors), $5 \%$ of managers thought that they did not need this knowledge, because they were knowledgeable in this field.

The answers to the questionnaire "What kind of knowledge and skills in communication management can you use in certain situations?" (21\% of future managers and $24 \%$ of directors); "Knowledge and skills related to conversation in everyday and professional pedagogical environment" ( $9 \%$ of graduate students and $7 \%$ of managers); "Ability to create and make a speech" (41\% of future directors and $48 \%$ of directors); "Knowledge and skills related to the dispute in everyday and professional pedagogical environment" (29\% of graduate students and $21 \%$ of managers).

We received the following answers to the question "What communication skills are important to you in yourself?": "persuade and inspire" (17\% of graduate students and $22 \%$ of managers); "Ability to activate the audience's attention during the performance" (35\% of future managers and $45 \%$ of directors); "Ability to analyze specific pedagogical communication situation" (26\% of graduate students and $20 \%$ of managers); "Ability to obtain appropriate speech means and rhetorical techniques taking into account the managerial situation" (22\% of graduate students); "The ability to predict the content and rhythm of a language event, the ability to build one's speech according to the laws of rhetoric" (13\% of directors). 
These are the answers to the question "What are your difficulties during communicative-management activity?": "Failure to competently, logically and clearly express their thoughts in all situations" (13\% of graduate students and $15 \%$ of managers); "Inability to create a figurative, expressive statement" ( $42 \%$ of future managers and $47 \%$ of directors); "Inability to use non-verbal and paraverbal communication tools in a congruent and effective manner" (21\% of graduate students and $17 \%$ of managers); "Self-doubt, lack of initiative, unwillingness to take on the role of leader of communication" ( $6 \%$ of future managers and $3 \%$ of directors); "Categorical evaluation, non-acceptance of the point of view of the interlocutor; lack of a positive attitude towards the interlocutor" (9\% of graduate students and 11\% of managers); "Lack of reflexive listening skills and ability to decipher the interlocutor's tactics and strategy" (7\% of graduate students and 4\% of managers).

According to the test results, it turns out that the quantitative indicators of the distribution of the level of positive-active attitude to communicative activity, positive motivation to communicative self-improvement of future managers and directors are slightly different: $25 \%$ of graduate students and $28 \%$ of managers have the initiative and creative level; $55 \%$ of graduate students and $58 \%$ of managers are at the functionally-adequate level, $20 \%$ of graduate students and $14 \%$ of managers are at the intuitively-situational level. The leaders of educational institutions are more motivated to communicate and more consciously feel the need for selfimprovement, since management activities daily require appropriate knowledge, communication management skills and communication psychology.

Therefore, as the study shows, quantitative data on the development of communicative competence among future managers and directors differ slightly and vary within $1.5 \%$; the respondents have the most formed motivational component of communicative competence, since the highest rates for future managers with an initiative-creative level of development of communicative competence at the ascertaining stage of the experiment are $25 \%$ of graduate students and $28 \%$ of directors; the least formed is the cognitive component, the lowest $13.5 \%$ of future managers and $14 \%$ of directors, respectively.

The study of the components of the development of communicative competence at the ascertaining stage of the experiment revealed that the masters are dominated by a functionally adequate level of development of communicative competence, namely $48.7 \%$ of future managers and $49.5 \%$ of managers. Initiative-creative level is held by $16.8 \%$ of graduate students and $17.5 \%$ of directors; $34.4 \%$ of future managers and $33 \%$ of managers have found an intuitive situational level.

The results of the staging experiment showed the objective underdevelopment of the cognitive and activity-communicative component of communicative competence of future managers, as it turned out that only one fifth of the respondents demonstrated an initiative-creative level of development of communicative competence.

\section{Conclusions}

We understand the communicative competence of the future manager of a comprehensive educational institution as a basic component of professional and managerial competence, which combines systemic communication knowledge (cognitive component), a complex of professionally relevant communication skills (initiative in communication, communicative openness, willingness to cooperate, tolerance, ability to improvise, creative imagination), significant qualities of a linguistic personality (activity-communicative component); reflexive skills in the ability to perform communicative-management activities (reflective component); as well as the desire of the graduate student to successfully carry out communication activities (motivational component).

After analyzing the results of the diagnostics, we came to the following conclusions:

- the most important condition for the development of communicative competence is the formation of communicative knowledge, skills and personally important qualities (enriched and developed connected communication, communicative openness, willingness to cooperate, co-creation, tolerance, ability to improvise, creative imagination, predicting communicative situations), readiness and ability of the graduate to successfully carry out communication and management activities and perform self-analysis, which should be done through analytical work under the supervision of a professor at the university;

- it is necessary to carry out systematic work on the analysis of peculiarities of communicative competence development of future managers while obtaining their master's degree;

- formation of communicative competence should be carried out taking into account the results of diagnostics of the levels of formation of qualitative and quantitative indicators of development of communicative competence of future managers, which will allow to carry out an individual approach of the professor to each student obtaining his master's degree;

- courses "Communication Management", "Psychology of Communication" in the system of training of future managers will ensure the formation of their communicative competence;

- $\quad$ it is possible to judge the level of communicative competence development of the future manager by his ability to predict the communicative situation, motivate the mutual work of the teaching staff and 
himself, analyse the specific communicative situation and obtain speech/linguistic means and techniques of communication; if he can solve interpersonal and business problems in the educational sphere, take part in professional interaction observing the cultural language norms of speech; if he has effective listening skills that promote productive communication; if he easily makes contact with other people; if he can consciously control the results of his activity, the level of his own development, the dynamics of personal communicative growth;

- it is necessary to develop a pedagogical set of measures aimed at developing the communicative competence of future managers, which will be the next stage of our work.

\section{References}

Androsova IV (2015) Struktura I model kommunikativnoy kompetentnosti menedzhera. Molodoy ucheny 9: 498500 .

BelGU 231 p.

Bodalev AA, Psikhologilya lichnosti, $1^{\text {st }}$ edn. (MGU: Moscow, Russia, 1988), 188 p.

Burlachuk LF, Morozov SN, Slovar- spravochnik po psikhodiagnostike, $3^{\text {rd }}$ edn. (Piter: St. Petersburg, 2002), $215 \mathrm{p}$.

Chechel ID, Potemkina TV, Firsova MM, Upravlencheskaya kompetentnost rukovoditeley obscheobrazovatelnykh organizacy, $1^{\text {st }}$ edn. (APKIPRO: Moscow, Russia, 2014), 184 p.

Glushchenko VV, Glushchenko II (2016) Motivirueschee I demotiviruyuschee obscheniye rukovoditelya s podchinennymi kak chast menedzhmenta organizacii. Mezhdunarodny nauchno-issledovatelskiy zhurnal 5 (47): 51-54. doi: 10.18454/IRJ.2016.47.237.

Kolyada CM (2007) Kommunikativnaya kompetentnost rukovoditelya. Delovoy kluch 10:12-15.

Kozyrev GI, Politicheskaya konfliktologiya, $1^{\text {st }}$ edn. (Forum: Moscow, Russian Federation, 2008), 432 p.

Kutsenko VG, Rechevoye mastersvo pedagoga-rukovoditelya. Upravleniye- deyatelnost professionalnaya, $1^{\text {st }}$ edn. (GUPM: St. Petersburg, Russia, 2001), 58 p.

Lazarenko IR (2000) Formirovaniye imidzha obrazovatelnogo ucherezdeniya kak upravlencheskoye novshestvo. Pedagog 9: 33-36.

Lomov BF, Metodologicheskiye I teoreticheskiye problemy psikhologii, $1^{\text {st }}$ edn. (Nauka: Moscow, Russia, 1984), $444 \mathrm{p}$.

Lukyanova MI (2007) Professionalnaya kompetentnost pedagoga: teoreticheskiy analiz ponyatiya. Upravleniye doshkolnym obrazovatelnym ucherezhdeniyem 1:72-81.

Menkin CM (2011) Kommunikativnaya kompetentnost: ot teorii k praktike formirovaniya. Srednee professionalnoye obrazovaniye 12: 3-5.

Obushak SI (2006) Kommunikativnaya kompetentnost kak sostavlayuschaya professionalnogo obrazovaniya menedzhera. Dissertaciya kandidata pedagogicheskych nauk. St. Petersburg: IOV RAO, 153 p.

Osipova TU, Kostina TM (2017) O vzaimosvyazyakh kommunikativnoy kompetentnosti I kommunikativnoy fleksibilnosti s kommunikativnoy kreativnostyu. Psikholog 2:90-125. doi: 10.7256/2409-8701.2017.2.22598

Parpura OA (2008) Razvitiye cennostnogo otnosheniya rukovoditeley shkol k sovershenstvovaniyu sobstvennoy kommunikativnoy kompetentnosti. Dissertaciya kandidata pedagogicheskykh nauk. Barnaul: AltGPU, 174 p.

Peresypkin AP (2002) Nauchno-metodicheskoe obespecheniye podgotovki shkolnykh moderatotov v sisteme dopolnitelnogo professionalnogo obrazovaniya. Dissertaciya kandidata pedagogicheskykh nauk, Belgorod:

Petrovskaya LA, Obscheniye- kompetentnost- trening, $1^{\text {st }}$ edn. (Smysl: Moscow, Russia, 2007), 146 p.

Podolyak YV, Lichnost I kollektiv: Psikhologiya voennogo upravleniya, $1^{\text {st }}$ edn. (Voenizdat: Moscow, Russia, 1989), 294 p.

Rozhdestvenskaya NN (2000) Podgotovka rukovoditeley obrazovatelnykh ucherezhdeniy k upravlencheskoy kommunikacii s presonalom $\mathrm{v}$ usloviyakh lichnostnoy orientacii obrazovaniya. Dissertaciya kandidata pedagogicheskykh nauk. Volgograd: VGSPU, 268 p. 
Stolyarenko LD, Psikhologiya obsheniya, $1^{\text {st }}$ edn. (Fenix: Rostov-on-Don, Russia, 2015), 288 p.

Sydorenko EV, Trening kommunikativnoy kompetentnosti $\mathrm{v}$ delovom vzaimodeystvii, $1^{\text {st }}$ edn. (Rech: St. Petersburg, Russia, 2007), 208 p.

Yefimochkina NB (2018) Kommunikacii v sistemakh upravleniya. Vestnik universiteta 10:15-22. doi: 10.26425/1816-4277-2018-10-15-22.

Yemelianov UN, Shchukov YM (1983) Socialno-psikhologicheskiy trening: problemy I perspektivy. Voprosy psikhologii 6:139-140. 